\title{
Kebijakan Geopolitik Poros Maritim Di Era Jokowi Dalamfilosofi Frame Ideologis
}

\author{
Laode Muhamad Fathun \\ UPN"Veteran "Jakarta \\ Email Lm_fathun@yahoo.co.id
}

\begin{abstract}
ABSTRAK
Tujuan penulisan paper ini adalah untuk mengetahui dan menjelaskan faktor yang mempengaruhi munculnya kebijakan geopolitik poros maritim di Era Jokowi.Metode penelitian yang digunakan adalah deskriptif analisis sebagai tipe penelitian. Sedangkan teknik pengumpulan data pada karya tulis ini adalah dengan cara wawancara, dokumen, pengamatan langsung, observasi partisipan dan untuk menambah data karya ini ditambahkan dengan telaah pustaka (library research), dengan berupaya mengumpulkan data- data yang berhubungan dengan permasalahan yang diteliti seperti, buku, jurnal, tabloid, surat kabar, dan internet. Dengan tempat penelitian seperti Perpustakaan Nasional di Jakarta, Kementrian Koordinator Bidang Maritim dan Sumberdaya di Jakarta serta Badan Keamanan Laut Di Jakarta. Kemudian teknik analisa data menggunakan teknik analisa kualitatif serta metode pengambilan kesimpulan dengan cara deduktif. Dengan hasil penelitian bahwa faktor yang mempengaruhi munculnya kebijakan geopolitik poros maritim di Era Jokowi yakni faktor interpretasi ideologis terkait proses perumusan kebijakan luar negeri poros maritim.
\end{abstract}

Keyword: Kebijakan, Poros Maritim, Jokowi, pengaruhideologis, geopolitik

\begin{abstract}
The purpose of writing this paper is to identify and explain the factors that influence the emergence of geopolitical pivot maritime policy in the Era Jokowi. Research method is descriptive analysis as a type of research. While data collection techniques in this paper is by way of interviews, documents, direct observation, participant observation and to add to this work the data added to the literature review (library research), to attempt to collect data that relate to the problems studied like, books, journals, tabloids, newspapers, and internet. With a study like the National Library in Jakarta, the Ministry of Maritime Affairs and Resource Coordinator in Jakarta and Maritime Security Agency in Jakarta. Then the data analysis using qualitative analysis techniques and methods by way of deductive conclusions. With the results of the research that the factor affecting the emergence of geopolitical pivot maritime policy in the Era Jokowi ideological interpretation of the factor related to the process of foreign policy formulation maritime shaft.
\end{abstract}

Keyword: Policy, Maritime Poros, Jokowi, the influence of ideological, geopolitical 


\section{Pendahuluan}

Filosofi kebijakan geopolitik maritim adalah sebuah kebijakan transformatifuntuk yang dimana Negara tersebut memahami kondisi struktur kekuatan morfologi Negara sebagai power politic.Dasar terbentuknya kebijakan tersebut adalahdengan asumsi negara bahwa wilayah maritim merupakan kekuatan potensial selain aspek wilayah darat.Pemikir teori geopolitik maritim seperti Ratzel, yang menekankan pendekatan Negara seperti halnya "hewan"(organism determinist, living space) atau negara di identikan seperti manusia yang butuh ruang untuk hidup untuk menjaga ruang tersebut agar tetap di kuasai, dikembangkan. Dengandasar filosofi tersebut morfologi wilayah Indonesia yang strategis sebagai negara pulau, Indonesia diharapkan bisa super power dalam orientasi pada geopolitik maritim.

Kondisi ini menandai bahwa ada hubungan antara negara dengan lingkungan tempat hidupnya atau wilayah geografinya. Filosofi teori maritim Ratzel mengidentifikasi bahwa faktor lingkungan atau geografi pastiakanberpengaruh pada proses pengambilan kebijakan negara atau the state political power. Teori Ratzel yang berkembang pada rentan tahun 1844-1904 mengansumsikan efek dari letak geografi ( bentuk, luas, sumberdaya alam, sumberdaya manusai, letak) merupakan indikator Negara dalam mempertahankan keberlangsungan hidupnya (organisme hidup). Ratzel mempredisikandimasa depan akan terjadi konstalasi politik dunia akan didominasi antara negara berciri maritim dan kontinental dalam upaya mengontrol dunia bahkan diamenyebut konstalasi akan terjadi pada kepemilikan Samudra Pasifik adalah sebagai power kehidupan masa depan Negara (Sri Hayati dan Ahmad Yani., 2007: 10-12) (Fathun, 2016).

Realitas inilah yang dikosntruksi oleh Jokowi berkenaan lahirnya kebijakan poros maritime.Kebijakan poros maritim memperleihatkan keciri khasan orientasi model kebijakan luar negeri Indonesia di era Jokowi walaupun dalam epistemologi yang berbeda.Prospek kekuatan politik ekonominya ada pada akses berbatasan langsung dengan Samudra Hindia dan Samudra Pasifik.Jokowi ingin mereformulasi Indonesia kepada identitas awalnya sebagai negara kepulauan dengan basis budaya maritim wawasan nusantara disertai segala upaya pengelolaan potensi maritim terhadap 17.000 lebih pulau yang terbentang dari sabang sampai merauke.

Kebijakan poros maritim merupakan karakter politik luar negeri Jokowi yang arahkan pada unsur (1) Membangun identitas budaya maritim dengan mengedepankan praktek diplomasi dan kerjasama antar negara, (2) meningkatkan peran global berbasis 
pada diplomasi middle power, (3) memperluas keterlibatan kerjasama di kawasan IndoPasifik,(4) mempertajam diplomasi publik ( $G$ to $G, G$ to $B, G$ to $C$. $P$ to $P$ ). Ciri khas kebijakan tersebut sudah terlihat ketika debat Capres dan Cawapres tahun 2014 yang lalu.Walaupun demikiansejumlah pilar tersebut tetap saja mengacu pada kebijakan luar negeri bersifat million friends zero enemy dengan tidak meninggalkan secara mutlak konsep SBY, dengan masih mengedapankanhubungan antar negara melalui peran diplomasi untuk memperluas jangkauan kerjasama sehingga menginginkan peran Indonesia dalam dunia internasional (Komisi Pemilihan Umum Republik Indonesia,Visi misi Jokowi -JK, 2014).

Pada lembar visi dan misi Jokowi -JK pada halaman ke 6 karakter kebijakan politik luar negeri Indonesia di era Jokowi memprioritaskan geopolitik maritime sebagai basis marketing politik ekonomi.Kebijakan geopolitik maritim ini di adopsi oleh teori geopolitik Alfred Thayer Mahan sebagai pencetus terori maritim sebagai bukti kongkrit bahwa kekuatan laut sebagaiinstrumen negara untuk mengontrol dunia.Kontrol laut berupa pengelolaan potensi laut yang baik telah dibuktikan oleh Amerika Serikat sebagai orientasi kekutan basis ekonomi dan pertahanan negara saat itu.

Di era Jokowi ingin memperlihatkanpower politic yang serius suntuk mengkapitalisasi potensi maritim Indonesia secara komprehensif.Keseriusan Jokowi terlihat saat dibentuknya Badan Keamanan Laut dengan terbitnya Instruksi Presiden no 178 tahun 2014 serta terbentuknya Kementrian Koordinator Bidang Maritim dan Sumberdaya RI sesuai Inpres nomor 10 tahun 2015. Berdirinya dua lembaga iniyakni Kementrian Koordinator Bidang Maritim yang membawahi empat kementrian yakni Kementrian ESDM, Kementrian Kelautan dan Perikanan, Kementrian Pariwisata, Kementrian Perhubungan sebagai fungsi koodinasi utamanya. Jokowi ingin menunjukan kembali kekuatan maritim adalah potensi kekuatan dan sumberekonomi nasional yang perlu di internasionalisasi.

Pada pertemuan diplomasi tingkat tinggi seperti di Beijing dan KTT Asia Afrika di Jakarta Jokowi menginternasionalisasi konsep politik maritimnya.Adalima pilar kebijakan geopolitik maritim yakni upaya membangun budaya maritim, membangun infrastruktur maritim, mengkapitalisasi sumberdaya maritim, penguatan diplomasi maritim serta pertahanan maritim.Jokowi mengarahkan Indonesia pada arah politik spasial maritim.Arah kebijakan politik luar negeri Jokowi membawa Indonesia memasuki abad "geopolitics". Teori ini, berangkat pada sifat negara yang libensraum, dimana setiap negara berlomba memperebutkan kekuasan dominasi baik negara kecil maupun negara besar dalam spasial 
dunia. Pendekatan ini berorientasi pada hubungan keseluruhan antara politik dan geografi, ekonomi dan secara khusus berkaitan dengan kebijakan politik luar negeri suatu negara. Knox Paul bahwa "is the state 's power to control space and territory and shape foreign policy of individual states and international political relations."(Makmur Suprianto, 2014:358).

Konsentrasi kebijakan luar negeri maritime Indonesia didukung oleh pernyataan Mentri KKP RI bahwa kapitalisasi sumberdaya maritim dengan baik , sudah cukup untuk membiayai APBN Indonesia. Lebih lanjut, menurut Pakar Hukum Laut Hasjim Djalal mengatakan bahwa negara maritim tidak sama dengan negara kepulauan. negara maritim adalah negara yang mampu memanfaatkan laut, walaupun negara tersebut mungkin tidak memiliki banyak laut, tetapi mempunyai kemampuan teknologi, ilmu pengetahuan, peralatan, dan lain-lain untuk mengelola dan memanfaatkan laut tersebut, baik ruangnya maupun kekayaan alamnya dan letaknya yang strategis. Oleh karena itu, banyak negara kepulauan atau negara pulau yang belum menjadi negara maritim karena belum mampu memanfaatkan laut yang sudah berada di dalam kekuasaannya.Sebaliknya, banyak negara yang tidak mempunyai laut atau lautnya sangat sedikit tetapi mampu memanfaatkan laut tersebut untuk kepentingannya, misalnya Singapura.negeri Belanda yang lautnya sangat kecil mampu menjelajahi Samudera Hindia dan menjajah Indonesia hingga ratusan tahun. Indonesia, menurut Hasjim Djalal, adalah negara kepulauan yang kini sedang menuju kembali atau bercita-cita menjadi negara maritim karena di masa lalu pernah menjadi negara maritim seperti di zaman Sriwijaya dan Majapahit. Di masa itu, bangsa Indonesia malah menjelajah jauh sampai ke Afrika Timur (Madagaskar) dan ke Pasifik Selatan (Dikutip Saat penulis mengikuti Seminar Nasional dan Sosialisasi Hukum Laut Kerjasama Kemenlu RI dan Fakultas Hukum UNHAS, Ruang Senat UNHAS 18 Mei 2013).

Oleh sebab itu, keseriusan Jokowi ingin mengkapitasliasi potensi maritim sebagai sumberdaya nasional menjadi marketing power untuk di kelola dengan baik tentunya untuk kepentingan pembangunan nasional.Dari konstruksi latar belakang di atas maka penulis merumuskan masalah bagaimna filosofi doktrin kebijakan poros maritim di era Jokowi?

\section{KAJIAN LITERATUR}

Dalam tulisan Mervyn Piesse dengan judul Indonesian Foreign Policy and the Regional Impact of its Maritime Doctrine tahun 2015 menuliskan bahwa kebijakan doktrin maritim di era Jokowi menunjukan konsistensi Indonesia untuk persoalan domestik yang harus di 
internasionalisasi. Kebijakan doktrin maritim tersebut menunjukan ketegasan Jokowi yang berangkat dari asumsi-asumsi kerugian materil dan non materil seperti pencurian ikan, pembajakan.Doktrin kebijakan tersebut menunjukan bahwa selama ini tidak ada kepercayaan public terhadap pemerintah Indonesia dalam mengatasi masalah tersebut yang selalu berulang setiap tahunya.Kebijakan doktrin maritim itu, menjadikan Indonesia merubah paradigma multilateral menjadi unilateral.Kondisi ini seperti " "Shock therapy" bagi Indonesia untuk mempertahankan hasil produktifitas hasil laut serta kedaulatan wilayah.

Dalam Iis Gindarsah and Adhi Priamarizki dengan judul Indonesia's Maritime Doctrine And Security Concernspaper ini menjelaskan bahwa kebijakan doktrin maritim Jokowi adalah kebijakan yang menunjukan perubahan yang signifikan. Perubahan tersebut terlihat keinginan Jokowi untuk menjadikan Indonesia sebagai Negara yang eksis dalam bidang maritim atau global exis maritime.Kebijakan tersebut bertumpu pada budaya maritim Indonesia yang multi etnis sebagai kekuatan.Membangun kembali Indonesia sebagai kekuatan maritim global merupakan aplikasi dari Trisakti Soekarno agar Indonesia jangan melupakan laut sebagai kekuatan nasional.Sehingga, dengan bertumpu pada perbatasan langsung dengan Samudra Hindia dan Samudra Pasifik, keinginan Jokowi membangun kembali Indonesia sebagai basis pertahanan maritim regional dan internasional.

Aaron L. Connelly dalam Sovereignty and the Sea: President Joko Widodo's Foreign Policy Challenges tahun 2015.Tulisan tersebut memaparkan bahwa Jokowi adalah seorang pembaru bagi Indonesia.Kebijakan eksis dalam bidang maritim menunjukan Jokowi konsen pada isu domestic yang berbeda dengan pendahulunya yakni SBY.Jokowi menunjukan sebagai seorang yang sederhana, datang dari desa tetapi dengan pemikiran global.Jokowi menunjukan diri sebagai seorang nahkoda yang membawa Indonesia sebagai negara yang menjadikan maritim sebagai isu internasional.Dengan konsep abstrak yang dimilikinya membawa dia pada seorang yang tidak memiliki pengalaman dalam panggung internasional.Pada poinya paper ini menjelaskan bahwa kebijakan doktrin maritim di akibatkan oleh pengaruh penasehat dan elit partai politik.Sehingga, Jokowi di isyaratkan sebagai pelaksana dalam implemntasi program-program partai politik.Sedangkan tulisan ini akan membuktikan bahwa kebijakan geopolitik poros maritim merupakan kebijakan intrepretasi ideologis. 


\section{KERANGKA TEORITIK}

Banyu Perwita dan Muhamad Yani menjelaskan bahwa kebijakan politik luar negeri sebuah negara adalah action theory yang menyangkut sikap, prilaku, nilai, ideologi yang dimiliki sebuah negara untuk diperjuangkan (Anak Agung ,Bannyu Perwita, dan Yan Yan,Muhamad Yani, 2005:47). Kemudian T. May Rudi melanjutkan bahwa sisi variabel dari kebijakan poltik luar negeri bertumpu pada keputusan-keputusan ( decision) dan kebijakan-kebijakan ( policies), yang di asumsikan untuk pemilihan tujuan tertentu, pemilihan sarana dan cara implementasi ((T. May ,Rudy, :2003:89).. Kemudian disimpulkan oleh Holsti bahwa kebijakan politik luar negeri sebuah negara terdiri ada empat komponen yakni : (1) orientasi kebijakan politik luar negeri, peran nasional, (3) tujuan dan (4) tindakan (Holsti,:1988).

Memahami konteks maritim maka tidak lepas pula dengan ancaman keamanan maritim Indonesia sebagai negara pulau.Kondisi tersebut di pahami sebagai analisis kemampuan suatu negara dalam melihat landasan fisik negaranya.Landasan fisik tersebut menyangkut tentang kondisi geopolitik negara tersebut.Sederhananya adalah hubungan antara kondisi fisik negara dengan kebijakan negara.Artinya ada relatifitas hubungan natara wilayah geografis negara dan politik yang disebut dengan teori geopolitik.

Pada dasarnya teiori ini disadari signifikansinya sejak zaman dahulu.Perspektif manusia melihat bagaimana keadaan alam atau lingkungan dalam hubungannya dengan perilaku politik manusia senantiasa mengalami perkembangan dan evolusi sejak pada pertama kalinya hal ini disadari.Geopolitik memelajari bagaimana keputusan politik dapat diambil secara tepat dan strategis dengan mempertimbangkan faktor geografis.Geografis dalam hal ini mengacu pada batas-batas geografis antar negara yang juga berarti batas politis. Geopolitik merupakan daerah irisan antara political science dengan political geography sehinga geopolitik atau dalam konteks lain hubungan antara geografi dan politik sering juga disebut human geography yang prinsipnya menyangkut hubungan antara political behavior dan psycal features. Artinya erat hubungan antara prilaku politik negara dan lingkungan geografinya.

Geografi suatu negara bisa saja membantu dalam hal kehidupan sosial, politik, ekonomi karena letak dan kondisi geografi adalah salah satu kunci dalam membangun dan mengembangkan kehidupan perekonomian suatu negara. 
Griffith menyatakan bahwa:Geopolitics is the study of the influence of geographical factors on state behaviour - how location, climate, natural resources, population, and physical terrain determine a state's foreign policy options and its position in the hierarchy of states (Martin, Griffiths dan Terry O'Callghan, :2002: 120).

Geopolitik adalah sebuah studi geografi yang dikaitkan dengan kondisi kebijakan luar negeri sebuah negara dan fenomena politik dengan asumsi bahwa kekuatan sebuah negara bergantung pada wilayahnya, sungai jalanan, bahan mentah dan makanan dan termasuk penduduknya, pemerintahnya, ekonominya dan budayanya.Secara abstrak, geopolitik tradisional menunjukkan hubungan dan pernyataan kausalitas antara kekuatan politik dan ruang geografis. Terminologi ini sering dianggap sebagai formulasi khusus yang berhubungan dengan kepentingan strategis relatif dari pentingnya potensi geografis dalam perspektif dunia internasional.Fokus utama teori geopolitik berhubungan dengan korelasi antara kekuatan dalam bidang politik, identifikasi wilayah inti dari perspektif internasional, dan hubungan antara kapabilitas laut dan darat yang dimiliki.

Dengan landasan fisik tersebutlah maka setiap pengambil kebijakan harus beradap tasi dalam model kebijakan luar negerinya.Sehingga, dalam perkara ini Jokowi yang baru terpilih sebagai presiden RI harus memahami secara komprehensif terkait dengan kondisi wilayah Indonesia terutama menyangkut keamanan maritimnya.Sebab hal ini menyangkut kemampuan Jokowi dalam beradaptasi untuk mempertahankan keamanan wilayah serta produktifitas hasil sumberdaya. Maka melihat kondisi itu Rosenau merumuskan model kebijakan luar negeri agar setiap pengambil kebijakan politik luar negeri memahami betul atas kondisi negaranya sehingga bisa beradap tasi terkait dengan kebutuhan ekternal dan internal negara tersebut.Rosenau membentuk skema agar memudahkan proses perumusan kebijakan adaptasi negara sebagai berikut:

\section{Gambar 1 Model Kebijakan Laur Negeri Adaptif}

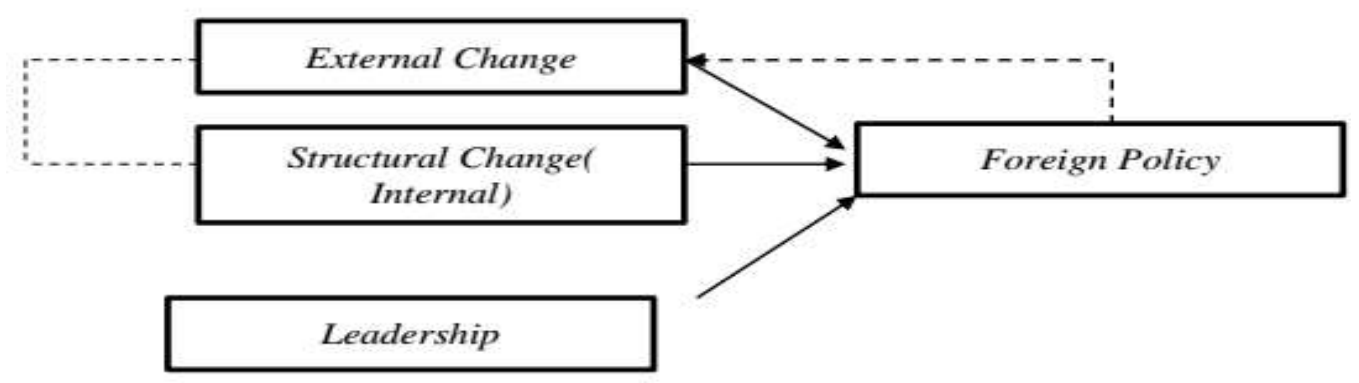

Sumber: James Rosenau.,1974 Comparing Foreign Policy:Theories , Findings and Methods, Sage Publication: New York.h.47. 
Aplikasi model kebijakan luar negeri menurut Rosenau ini , memungkinkan setiap akor melalui decision maker(Leadership) yang dimaksudkan adalah Jokowi yang harus menyadari kebutuhan dalam negerinya atau politik domestik atau kondisi internal negara.Selain itu, tentunya berjalan seiring dengan kebutuhan eksternal negara terkait kebutuhan domestiknya. Sehingga, antara kebijakan domestik dan kebijakan luar negeri sesuatu yang tidak bisa dipisahkan dalam politik internasional yang berada dalam sebuah sistem internasional.Sistem yang internasional yang dimaksudkan adalah hubungan eksternal tentunya dalam konteks Indonesia ditempuh melalui diplomasi.

Menurut Rosenau proses perumusan kebijakan luar negeri negara oleh aktor decision maker sang pelaku harus mengetahui dengan benar presepsi politik domestik dan estimasiatau proses adaptasi terhadap objek yang akan di capai. Presepsi tersebut adalah bagaimana interpretasi terhadap isu dari pengalaman-pengalaman negara tersebut baik didapatkan dari tim penasehat, akademisi, analis dll. Hal ini berguna untuk melihat kapabilitas kemampuan dalam kepemilikan power sebagai estimasi dan kalkulasi terkait kemampuan yang menyangkut yang nyata misalnya militer, jumlah penduduk, ekonomi dalam bentuk kebutuhan bisa mempengaruhi kebijakan negara. Selain itu, power tidak nyata seperti karakter nasional, nilai moralitas, norma, hukum nasional bisa juga mempengaruhi proses pengambilan kebijakan.

Model adaptasi ini akan di gunakan oleh penulis berangkat dari analisis penulis bahwa Jokowi sebagai pemimpin yang baru terpilih yang minim akan pengalaman membutuhkan adaptasi terhadap kondisi internasional Indonesia dalam hal ini adalah keadaan politik domestik, menyangkut kebijakan struktural semasa SBY. Model ini akan melihat bagaimana proses perumusan kebijakan luar negeri Jokowi dalam orientasi maritim terutama aktor-aktor yang terlibat dalam proses tersebut. Dengan minimnya pengalaman Jokowi yang baru terpilih cenderung proses perumusan kebijakan geopolitik maritim merupakan pengaruh kondisi struktural atau kondisi internal. Sehingga Jokowi hanya sebagai leader yang hanya menerima jadi dalam proses perumusan tersebut. Dalam konteks ini Jokowi sebagai leader hanya berbekal pada pengaruh marketing politiknya terkait dengan karakter kepemimpinanya yang demokratis dan sosiologis, sederhana, dan tidak statsis. Akibatnya, dengan modal tanpa pengalaman dalam urusan luar negeri atau hubungan eksternal maka Jokowi harus beradaptasi dengan sejumlah masukan-masukan politis terkait dengan kebutuhan internal dan eksternal Indonesia terutama terkait dengan geopolitik maritim Indonesia yang selama ini tidak dikelola dengan baik. Maka munculah rumus Rosenau yakni $\mathrm{Pt}=\mathrm{Lt}+\mathrm{Et}+\mathrm{St}$.Pt=Kebijakan Politik Luar Negeri, Lt=Kepemimpinan 
,Et=Perubahan Eksternal, St=Perubahan struktural Internal (James Rosenau.,1974:.47, Anak Agung dan Muhamad Yanyan, 2005).

Rumus Rosenau ini merupakan penyederhanaan dalam karakter kekuatan nasional yang dimiliki oleh negara dalam politik internasional yang dicetuskan oleh sejumlah ahli politik seperti Morgenthau yang membaginya dalam 8 unsur kekuatan nasional negara. Adapun keempat pola adaptasi itu, adalah: a) preservative adaptation (sikap responsif terhadap permintaan dan perubahan lingkungan internal dan ekternal); b) acquiescent adaptation (bersikap peduli pada perubahan internal dan ekternal); c) intransigent adaptation (sikap responsif terhadap lingkungan internal); dan d) promotive adaptation (bersikap acuh terhadap lingkungan internal dan ekternal).Dari model adaptasi tersebut teori ini akan dikombinasikan untuk menganalisis proses perumusan kebijakan luar negeri oleh Jokowi terkait dengan struktur geopolitik Indonesia.

\section{Pembahasan}

Poin ini membuktikan hipotesa penulisbahwa kebijakan kebijakan gopolitik poros maritim adalah intrepretasifilosofi ideologis.Ideologis yang dimaksudkan adalah partai politik, dan elit politik dan periodis sejarah yang membawa Jokowi dalam memenangkan kontestasi pemilihan presiden.Oleh karena itu, kebijakan luar negeri Indonesia tidak bisa di pisahkan dengan aktor-aktor yang bermain didalamnya.Maksudnya apakah konsep kebijakan tersebut lahir dari model holistic atau wholistic.Seperti yang dikatakan oleh Alext Mint

Foreign policy choices range from the dramatic to themundane. Leaders make decisions to go to war, make peace, form an alliance, establish diplomatic relations, implement a position on nuclear nonproliferation, impose economic sanctions, or ratify global environmental agreements. The focus of this book is this broad range of decisions. the type of the decision (one-shot, sequential, interactive, group), The level of analysis in foreign policy decision making (the individual, group, coalition). foreign policy decisions (the decision environment, psychological factors, international factors, and domestic influences)(Alex Mintz, 2010-3-4).

Decisions can be made based on holistic, heuristic, or wholistic search (Sage 1990, 239-242). Holistic search involves a thorough examination of all the alternatives, dimensions, and implications of the decision. Heuristic decisions are made while employing cognitive shortcuts. Wholistic decisions are made while disregarding the components of the decision. Such decisions are intuitive, involving standard operating procedures (SOPs) and/or the use of analogies (ibid.).Heuristic and wholistic searches are more process oriented than holistic searches ( Alex Mintz, 2010:17). 
Melihat konsep tersebut di atas, Jokowi yang terpilih sebagai presiden pada tahun 2014 minim pengalaman di panggung dunia internasional yang berbeda jauh dengan SBY. Terbukti dengan adanya tim 11 yang merupakan kumpulan para akademisi dalam berbagai bidang ilmu, sebut saja Luhut Panjaitan dari Militer, Rizal Sukma dari peneliti, kemudian Wiranto, Megawati serta ideologi partainya yang merupakan warisan ideologi Soekarno. Akibatnya independensi kebijakan luar negeri Jokowi rentan akan pengaruh dari penasehatnya.Dengan demikian, filofosi kebijakan poros maritime sangatlah holistic.

Faktualnya adalah bagaimana pengaruh orang-orang terdekat dari Jokowi, namun yang paling berpengaruh dalam hal ini adalah ideologi partai politik.Jokowi adalah kader dari PDIP dan ketika Jokowi ditunjuk untuk menjadi Capres karena elektabilitasnya tinggi. PDIP dan peran Megawati sebagai ketua umum, dan Puan Maharani yang menjabat ketua legislatif PDIP di DPR serta pengaruh historis Soekarno dengan konsep negara baharinya. Ideologi PDIP dalam konsep trisakti Soekarno menjadi cita-cita yang harus diwujudkan.Dengan basis filosofi gotong royong sebagai semboyan mengantar Jokowi sebagai presiden RI ke 7.Yang mengejutkan adalah ketika konfrensi pers Megawati pernah mengatakan "Jokowi adalah petugas partai".Dalam konteks ini sepertinya Jokowi terlihat seolah menjadi boneka politik PDIP karena kegagalan Megawati. Model ideologi trisakti Soekarno yakni berdaulat politik, berdikari ekonomi serta berkepribadian kebudayaan, Jokowi yang terlihat menerima tanggung jawab sepertinya hanya bermodal pada pengalaman politik dengan marketing blusukan, kesederhanaan, seolah hanya menjadi alat untuk memuluskan ideologi politik partai terlihat dengan begitu banyaknya tim sukses yang mau bekerja untuk Jokowi baik dari pihak akademisi hingga praktisi dan TNI.

Menurut penulis bahwa ide besar tentang konsep filosofi doktrin kebijakan poros maritim memeng sangat holistic, artinya dengan terbentuknya model kebijakan tersebut bukan murni pemikiran Jokowi. Hal ini di sebabkan oleh Jokowi membuka diri untuk diberi sejumlah informasi terutama dari tim suksesnya. Menurut penulis mengapa hal ini di lakukan, sepertinya ada kolaborasi antara Jokowi yang di awal-awal pencalonannya di anggap sebagai "petugas partai" untuk membuat kecirikhasan terhadap model kebijakan luar negerinya. Walaupun hal tersebut hanyalah intrepretasifilosofi ideologis baik dari kilas balik sejarah maupun ideologi partai. Dengan demikian Jokowi dengan minimnya pengalaman harus open image atau keterbukaan terhadap semua pihak terkait masalah internal atau struktural dan masalah eksternal terkait hubungan internasional.

Konteks inilah Jokowi melakukan adaptasi terhadap masalah-masalah tersebut.Faktualnya walaupun Jokowi bukan orang berpengalaman didalam hubungan 
internasional dan kebijakan luar negeri, sebagai kepala negara Jokowi harus melibatkan diri dan sebagai tanggung jawab kepemimpinannya.Jokowi sebagai presiden harus bisa menginterpretasi kebutuhan domestik yang sejalan dengan kebutuhan eksternal.Adaptasi Jokowi melihat kondisi internal yang harus di internasionalisasi. Dari empat model adaptasi yang dalam teori Rosenau yakni hanya tiga yang menurut penulis tepat pada adaptasi Jokowi yakni: a) preservative adaptation (sikap responsif terhadap permintaan dan perubahan lingkungan internal dan ekternal); b) acquiescent adaptation(bersikap peduli pada perubahan internal dan ekternal); c) intransigent adaptation (sikap responsif terhadap lingkungan internal).

\section{Gambar 2 Aplikasi Model Kebijakan Luar Negeri Adaptif}

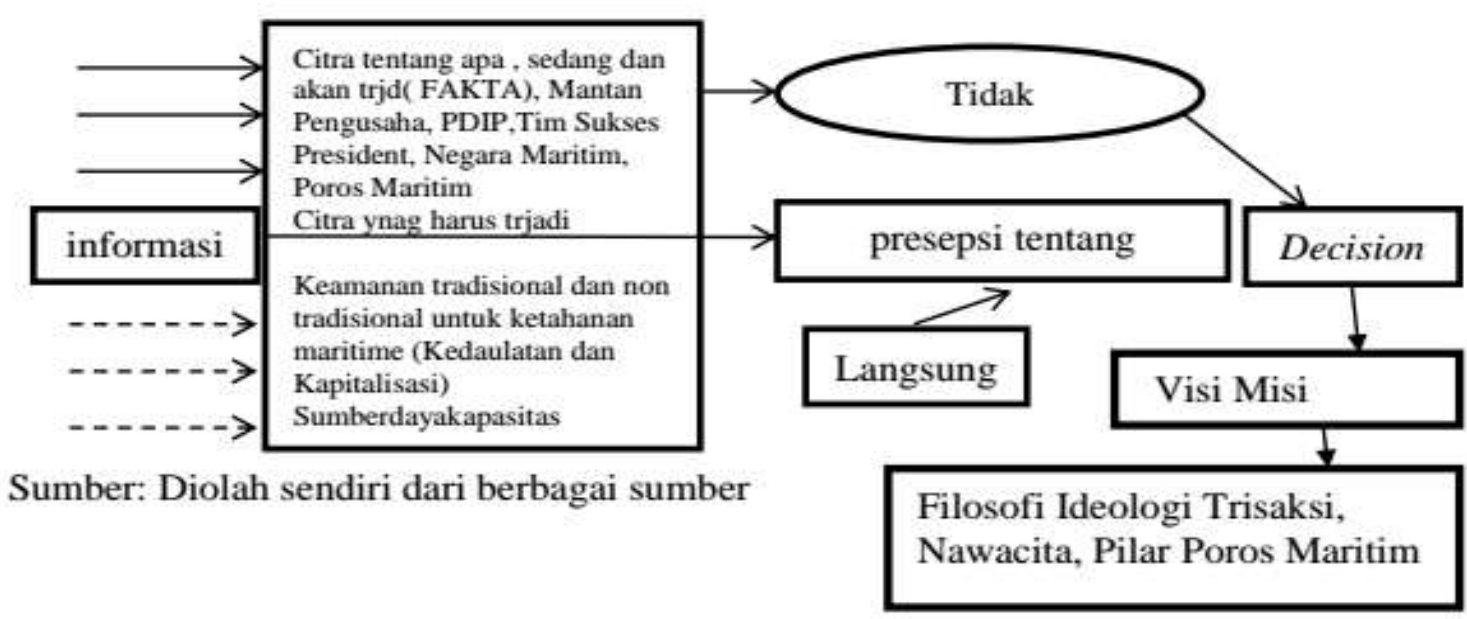

Maksud skema di atas adalah pada tataran informasi proses pengambilan kebijakan oleh Jokowi dipengaruhi oleh informasi yang tidak langsung dan langsung. Informasi yang langsung berupa garis bukan terputus-putus menunjukan proses informasi sangat ideologis atau istilah sangat holistic. Dalam tataran ini informasi yang masuk pada pengambil kebijakan dipengaruhi oleh bisiskan ideologis tentang realitas yang akan terjadi. Berkaitan dengan masalalu, partai politik, orientasi kebijakan dan citra politik.Akibatnya prosesnya bisa dikatakan tidak langsung dari si pembuat kebijakan. Sehingga, tataran kebijakan akan berpengaruh pada filosofi ideologis.

Pada lain isi informasi yang berbentuk garis putus-putus ini merupakan informasi di karenakan close imagei. Orientasi kebijakan geopolitik maritim yang juga terkait dengan model masalah keamanan maritim itu sendiri membuat Jokowi trauma akan hal tersebut. Sehingga, proses kebijakan menjadi langsung dan menjadi orientasi bahwa keamanan potensi maritime harus dikelola dan dikapitalisasi dan di pelihara.Dari masalah tersebutlah 
maka Jokowi menggunakan instrument tegas terkait dengan masalah konvensional dan non konvensional dalam bidang maritime. Bidang konvensional seperti sengketa wilayah, sedangkan non konvensional terkait dengan peredaran narkoba, pencurian ikan, senjata illegal, teorisme maritim yang secara keseluruhan merupakan ancaman wilayah maritime terhadap potensi maritim ( Lihat (Fathun, 2016) (Susanto dan Dicki R. Munaf, 2015) , Angga Nurdin Rachmat, 2015)).

Dari model adaptasi di atas ada korelasi dimana Jokowi sebagai decision maker pada variabel decisionyang baru terpilih sebagai presiden harus menyadari dirinya bahwa dia adalah seorang nahkoda dalam kebijakan geopolitik maritim.Jokowi harus menerima perubahan transformasi tanggung jawab yang di terimanya dari gubernur menjadi presiden.Jokowi dengan membawa harapan baru harus terbiasa dengan model struktural kebijakan yang ada yang yang konsen sebagai negara kontinental. Dengan membawa harapan baru maka dari sejumlah tim sukses itulah muncul permintaan-permintaan yang digeneralisasi sebagai masalah pokok bangsa yang tertuang dalam visi misinya tentang tiga masalah utama bangsa Indonesia yakni a) merosotnya wibawa negara menyangkut negara tidak mampu memberi rasa aman kepada warganya, masalah kedaulatan negara, HAM, dan ketidak percayaan masyarakat pada isnttitusi negara, b) merosotnya sendi-sendi ekonomi terkait dengan kesenjangan dan kemiskinan antar wilayah, ketergantungan pangan, eksploitasi sumberdaya alama yang merusak lingkungan, negara tidak mampu memanfaatkan sumberdaya nasional yang bersifat nyata dan tidak nyata. Akibatnya kualitas hidup tidak baik disertai pelayanan kesehatan yang layak menjadikan tingkatan pendapatan nasional pun merosot berujung pada utang luar negeri yang semakin meningkat.c) krisis dan intoleransi bangsa terkait dengan semakin tidak mampunya negara dalam mengelola keberagaman, gotong royong dan budaya lokal terabaikan sehingga terjadi politik setarian.Akibatnya identitas bangsa memudar dan begitu pula dengan budaya nasional.

Berangkat dari tiga masalah bangsa di atas kemudian Jokowi ingin mengembalikan negara pada pada identitas awalnya dengan meneguhkan kembali jalan ideologis. Jokowi meyakini bahwa dengan jalan ideologis yakni semangat Pancasila 1 Juni 1945 untuk menegakan kembali kedaulatan, martabat dan kebanggaan sebagai sebuah bangsa serta membuat kepercayaan publik meningkat pada institusi negara dengan semboyan gotong royong. Selain itu, Trisakssi Soekarno sebagai jalan untuk memulihkan kembali harga diri bangsa yang bermartabat dan sederajad dalam pergaulan antar bangsa. Realitas ini ditempuh dengan mengembalikan negara pada a) berdikari dalam bidang politik 
menyangkut membangun demokrasi dengan kedaulatan rakyat menjadi nilai dan karakter bangsa dengan jiwa gotong royong, b) berdikari dalam bidang ekonomi yakni mengembalikan demokrasi ekonomi kepada rakyat sebagai bagian dari pembangunan nasional, serta penglolaan sumber-sumber produksi di gunakan untuk kepentingan rakyat, serta c) kepribadian dalam kebudayaan menyangkut mengelola kebinekaan dengan semangat goyong royong sebagai identitas nasional.

Setelah memahami ketiga masalah bangsa tersebut maka Jokowi harus melakukan perubahan atau adaptasi terhadap masalah itu.Sebagai pemimpin yang terpilih sebagai presiden dengan tujuan mengembalikan Indonesia pada formulasi ideologis maka Jokowi merumuskan visi dan misi sebagai solusi dari ketiga masalah tersebut. Dalam mewujudkan visi Jokowi yakni terwujudnya Indonesia yang berdaulat, mandiri, dan berkepribadian berdasarkan filosofi gotong royong ditempuh melalui misi:

a) Mewujudkan keamanan nasional yang mampu menjaga kedaulatan wilayah, menopang kemandirian ekonomi dengan mengamankan sumberdaya maritim, dan mencerminkan kepribadian Indonesia sebagai negara kepulauan.b) Mewujudkan masyarakat maju, berkeseimbangan dan demokratis berlandaskan Negara hukum.c) Mewujudkan politik luar negeri bebas-aktif dan memperkuat jati diri sebagai negara maritim. d) Mewujudkan kualitas hidup manusia Indonesia yang tinggi, maju dan sejahtera. e) Mewujudkan bangsa yang berdaya-saing,f) Mewujudkan Indonesia menjadi negara maritim yang mandiri, maju, kuat, dan berbasiskan kepentingan nasional g) Mewujudkan masyarakat yang berkepribadian dalam kebudayaan.

Korelasi antara visi dan misis tersebut menjadi landasan Jokowi untuk mengatasi segala masalah bangsa. Menyikapi adaptasi terhadap masalah tersebut terhadap perbuhan internal dan eksternal negara maka terbentuklah sembilan agenda prioritas Jokowi dalam agendanya sebagai presiden.Nawacita tersebut sudah mencakup dan mewakili semua masalah bangsa yang di terjemahkan dari filosofi pancasila dan trisakti Soekarno.Nawacita tersebut menjadi adaptasi ketiga Jokowi terhadap kondisi internal yang menyangkut Indonesia sebagai negara maritm.Pada poin pertama Nawacita Jokowi utnuk melindungi segenap bangsa dan negara dengan rasa aman melalui politik bebas aktif, keamanan nasional yang terpercaya dan membangun kembali pertahanan trimatra TNI untuk memperkuat jati diri bangsa sebagai negara maritim. Sebagai negara maritim Jokowi akan mengamankan kepentingan maritim baik sumberdaya maupun batas negara menyangkut kedaulatan negara dengan konteks kerjasama regional dan multilateral salah satunya adalah menakikan anggaran pertahanan menjadi 1,5 persen dari GDP. 
Dari misi Jokowi yang telah dituliskan di atas ada tiga poin yang di menjadi agenda Jokowi sebagai presiden terkait negara maritim.Bisa di identifikasi bahwa ada keseriusan dari Jokowi ingin mengembalikan Indonesia sebagai negara maritim myang telah lama memudar.Dari misi tersebut terlihat jelas bahwa Jokowi ingin kembali mengkapitalisasi sumberdaya maritim dan menjaga kedaulatan maritim Indonesia.Hal, ini tentunya berawal dari munculnya ancaman-ancaman terhadap kedaulatan maritim Indonesia disertai dengan produktifitas sumberdaya maritim yang tidak dikelola dengan baik.Sehingga, memudarnya memudarnya budaya maritim selama ini akibat terlalu lama Indonesia melihat dirinya sebagai negara kontinental yang di akibatkan oleh kolonialisme Belanda yang ditambah dengan dominasi Soeharto sebagai negara agraris yang dilanjutkan oleh pemimpinpemimpin setelahnya yang tidak spesifik menjadikan maritim sebagai agenda prioritas negara.

Orientasi keseriusan Jokowi ini terlihat pada forum KTT Asia Timur Jokowi berpidato akan landasan kebijakan maritimnya dalam lima pilar yakni Pertama, akan membangun kembali budaya maritim Indonesia. Sebagai negara yang terdiri dari 17 ribu pulau, bangsa Indonesia harus menyadari dan melihat dirinya sebagai bangsa yang identitasnya, kemakmurannya, dan masa depannya, sangat ditentukan oleh bagaimana mengelola samudera. Kedua, akan menjaga dan mengelola sumber daya laut, dengan fokus membangun kedaulatan pangan laut, melalui pengembangan industri perikanan, dengan menempatkan nelayan sebagai pilar utama. Kekayaan maritim akan digunakan sebesarsebesarnya untuk kepentingan rakyat. Ketiga, akan memberi prioritas pada pengem-bangan infrastruktur dan konektivitas maritim, dengan membangun Tol Laut, deep seaport, logistik, dan industri perkapalan, dan pariwisata maritim. Keempat, melalui diplomasi maritim, menjaga semua mitra-mitra Indonesia untuk bekerjasama di bidang kelautan ini.Jokowi mengatakan berupaya menghilangkan sumber konflik di laut, seperti pencurian ikan, pelanggaran kedaulatan, sengketa wilayah, perompakan, dan pencemaran laut.Laut harus menyatukan, bukan mpemisah antar negara.Kelima, sebagai negara yang menjadi titik tumpu dua Samudera, Indonesia memiliki kewajiban untuk membangun kekuatan pertahanan maritim.Hal ini diperlukan bukan saja untuk menjaga kedaulatan dan kekayaan maritim, tetapi juga sebagai bentuk tanggungjawab dalam menjaga keselamatan pelayaran dan keamanan maritim.

Selain itu, dalam KTT Asia Afrika tahun 2015 yang lalu dengan agenda menjadi bahasan adalah (a) menelaah kembali dasasila bandung yang sudah dituliskan sebelumnya, (b) meningkatkan kembali kerjasama strategis negara-negara Asia Afrika, serta (c) 
mendukung deklarasi kemerdekaan Palestina. Penjabaran poin (b) inilah yang terkait dengan maritim. Pada pilar inilah menjadi perbedaan arah kebijakan luar negeri Jokowi yakni penguatan kerjasama maritim, dimana Jokowi menginginkan untuk menjadi poros maritm dunia(blue economic power), mengintenskan konektivitas serta mobilisasi bisnis ,dan (3) berhubungan dengan sosial budaya, seperti gender, diplomasi bencana, migrasi, pemuda.Pada pertemuan tersebut juga terjadi Reinvigorating The New Asian-African Strategic Partnership (NAASP) yang di tetapkan pada tahun 2005 silam. Intinya pada pilar-pilar tersebut menyangkut Dalam kelima pilar tersebut pada intinya menekankan pada budaya maritim, sumberdaya maritim, infrastruktur maritim, diplomasi maritim serta pertahanan maritim.

Keseriuan Jokowi dalam adaptasi model Rosenau pada bagian ketiga di atas terkait responsif terhadap lingkungan internal inilah maka Jokowi menjadikan isu maritim yang merupakan isu domestik di internasionalisasi sebagai kebutuhan domestik sekaligus kebutuhan eksternal Indonesia. Kondisi ini terbukti pada dua KTT yang disebutkan di atas. Hal ini sudah tertuang dalam visi misi Jokowi pada halaman ke 12 yakni Jokowi ingin mengembalikan Indonesia kepada identitas awalnya sebagai negara pula dengan metode pelaksanaan diplomasi dan kerjasama internasional. Upaya Jokowi ini di bentuk dalam lima agenda yakni : a) diplomasi maritim terkait masalah batas negara, b) menjamin integritas wilayah dan masa depan kesejateraan pulau-pula terluar, c) mengamankan SDA dan ZEE, d) mengintensifkan diplomasi pertahanan serta e) meredam rivalitas anta negara terutama sengketa territorial.

Dari sinilah Jokowi merasa peduli akan pentingnya sumberdaya maritim untuk dikelola sebagai basis kekuatan ekonomi dan pertahanan. Jokowi ingin menjadikan isu domestic sebagai agenda kebijakan luar negerinya atau Jokowi ingin bermain pada konsep unilateralisme global exis maritime. Sehingga, dengan basis paradigma kerugian-kerugian ekonomi dan non ekonomi akibat merosotnya produkstifitas sumberdaya ekonomi terkhusus ekonomi maritim maka Jokowi sangat responsif akan kondisi tersebut. Belum lagi terkait dengan ancaman kedaulatan negara yang berbasatan laangsung dengan 10 negara Asia Pasifik yang sepenuhnya belum terselesaikan.Dalam konteks inilah Jokowi sadar betul konsekuensi sebagai negara kepulauan yang dilematis. Pada satu sisi letak strategis memicu potensi yang besar, tetapi disisi lainya justru rawan akan adanya ancaman aakibat struktur geeopolitiknya.

Dengan demikian, bisa disimpulkan bahwa kebijakan geopolitik poros maritim Jokowi sangat ideologis berangkat dari filosofi Pancasila serta Trisaksi Soekarno. Artinya 
kebijakan tersebut sudah diramu dengan baik oleh para elit parta politik beserta tim sukses Jokowi sehingga Jokowi hanya sebagai pelaksana semata. Selain itu juga, bahwa kebijakan ini membawa Indonesia pada konteks percaturan geopolitik dunia pada politik spasial maritim. Akibatnya kebijakan ini sangat militeristik dan unilateral yang juga dipengaruhi oleh tim suksesnya yang sebagian besar adalah TNI. Walaupun geopolitik maritim lahir dari seorang Alfred Mahan seorang AL namun kondifikasi atau kontekstual Indonesia sebagai negara pulau menjadikan teori geopolitik Mahan bisa di adopsi oleh Indonesia sebagai paradigma identitas nasional dalam kebijakan politik luar negerinya. Walaupun Jokowi menyadari betul akan kondisi geopolitk Indonesia yang strategis sebagai potensi nasional akan tetapi disisi lainya adalah kondisi tersebut cenderung menjadi titik rawan terhadap ancaman-ancaman terhadap kedaulatan dan produktifitas negara sebab Indonesia tersusun atas pulau-pulau.

\section{KESIMPULAN}

Kesimpulan terkait model kebijakan luar negeri Jokowi merupakan pengaruh ideologis terbukti pada hasil analisa diatas.Dimana kebijakan luar negeri Jokowi dengan ide poros maritim merupakan bisikan dari sejumlah orang yang menjadi bagian dari kesusksesan Jokowi memimpin Indonesia. Pengaruh ideologis maksudnya adalah partai politik yang menaungi Jokowi, peran ketua partai, peran ketua fraksti di DPR, kader partai serta peran pengalaman historis, para akademis,praktisi dan TNI. Terjemahanya adalah peran PDIP, Megawati, Puan Maharani, Rizal Sukma, filosofi Soekarno,dan TNI.

Kebijakan poros maritim sangat militeristik dan karena dipengaruhi oleh tim sukses Jokowi yang juga dari kalangan TNI seperti Luhut Panjaitan, Riamizad Riyakudu, Hendropryiono, yang kemudian masuk Wiranto dari partai HANURA. Kebijakan ini menjadikan Indonesia sangat unilateralisme menganggap dirinya kuat dengan potensi laut yang dimilikinya. Kekuatan samudra Hindia, Samudra Pasifik secara geopolitik adalah tumpuan kebijakan pertahanan poros maritim. Kebijakan ini membuat Indonesia seperti konsep realisme klasik atau humanism determinist.Dimana mengagap dirinya sebagai negara yang tidak aman berkaca pada pengalaman kerugian ekonomi politik akibat tidak dikelolanya sumberdaya maritim.

Sehingga, dengan konsep ideologis ini menjadikan Indonesia sangat menggabungkan ide-ide realisme offensif Mearsheimer dan realisme defensive Stephen Walt.Uniateralisme itu terbentuk dengan penenggelaman kapal, peletakan radar baru di 
kawasan perbatasan, model doktrin pertahanan outward looking.Didukung oleh konsep Tri Matra TNI dengan doktrin pertahanan rakyat semesta.

Jadi perumusan kebijakan luar negeri ini sangat ideologis yang merupakan perkembangan model kebijakan Soekarno dengan negara bahari.Yang saat itu pesan Sokarno berharap bertumpulah pada lautan dan jangan menjadi jongos di negeri sendiri.Sehingga, pola perkembanganya adalah konsep ideologis trisakti Soekarno dengan basis filosofi gotong royong menjadikan kebijakan maritim Jokowi terbentuk. Walaupun dalam proses implemntasinya dilapangan pasca terpilihnya Jokowi menjadi presiden proses pengambilan keputusan sangat wholistic dari awal adalah basis holistic.

\section{DAFTAR PUSTAKA}

Banyu Perwita, Anak Agung dan muhamad Yani, Yanyan.Pengantar Studi Hubungan Internasional. Remaja Rosdakarya.Bndung.2005.

Carlsnaes,Walter,Dkk.Handbook of International Relational trjmh. Nusamedia .Bandung.2013.

Connelly , Aaron.Indonesian Foreign Policy Under President Jokowi, Lowy Institute For International Policy.2014.

Griffiths, Martin.International Relations Theory for the Twenty-First Century An introduction. New York.Routledge.2007.

Hayati ,Sri dan Yani, Ahmad. Geografi Politik.PT. Rafika Aditama.Bandung.2007.

Holsti , K.J. Politik Internasional Kerangka Untuk Analisis. PT.Erlangga. Jakarta.1988.

Hudson,V.M.The History and Evolutions of Foreign Policy AnalysisiSmith , A Hadfield and T. Dunne (eds)Foreign Policy theories, actors, cases.Oxford University Press.Oxford.2008.

Kissinger, Henry. Domestic Structure and Foreign Policy, In Hanrieder ,Wolfram, . 1971, Comparative Foreign Policy Theoretical.David Mc KAY Company In.New York.

Mahan ,Alfred Thayer.The Influence of Sea Power Upon History.1660-1783.

May ,Rudy T. Studi Strategis Dalam Transformasi Sistem Internasional Pasca Perang Dingin. PT.Rafika Aditama. Bandung.2002.

Muhamad Fathun, Laode . Percikan Pemikiran Teoritis Dalam Kompleksitas Isu-Isu Hubungan Internasional.Magister Hubungan Internasional UMY \& Komojoyo Press.Yogyakarta.2016.

Nurdin, Rachmad Angga. Keamanan Global. Alfabeta. Bandung.2015.

Suprianto, Makmur. Tentang Ilmu Pertahanan. Yayasan Obor Indonesia.Jakarta.2014.

Susanto, Munaf, Dicky R. Komando dan Pengendalian Keamanan dan Keselamatan Laut. Berbasis Sistem Peringatan Dini. Gramedia. Jakarta.2015. 
Tuathail ,Gearoid O, Dkk.The Geopolitics Raeder.Routledge 11 .New Fetter Lane.London.1998a.

Rethinking Geopolitics. Routledge11 New Fetter Lane, London EC4P 4EESimultaneously Published.USA and Canada.1998b.

Warsito ,Tulus. Teori- Teori Politik Politik Luar Negeri. Keterbatasan dan Relevansinya.BIGRAF Publishing. Yogyakarta.1998.

\section{Jurnal}

Connelly, Aaron L.Sovereignty and the Sea: President Joko Widodo's Foreign Policy Challenges,Contemporary Southeast Asia Vol. 37, No. 1 (2015), pp. 1-28DOI: 10.1355/cs37-1a.

Gindarsah ,Iis dan Priamarizki, Adhi,Indonesia's Maritime Doctrine And Security Concerns, Rajaratnam School Of International Studies, Policy Paper, RSISPublications@ntu.edu.sg.

Piesse, Mervyn,Indonesian Foreign Policy and the Regional Impact of its Maritime Doctrine, FDI Research Analyst Indian Ocean Research Programme, Independent Strategic Analysis Of Australia 's Global Interests 